\title{
Physical and Chemical Properties of Water and Sediments,
}

Grand Portage and Wauswaugoning Bays, Lake Superior, Grand Portage Indian Reservation, Northeastern Minnesota, 1993-96

By James F. Ruhl

U.S. Geological Survey

Open-File Report 97-199

Prepared in cooperation with the

Grand Portage Indian Reservation Tribal Council

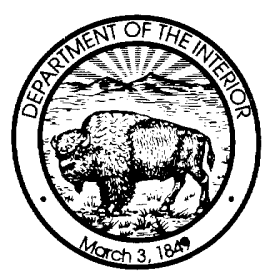

Mounds View, Minnesota 1997 


\section{U.S. DEPARTMENT OF THE INTERIOR \\ BRUCE BABBITT, Secretary \\ U.S. GEOLOGICAL SURVEY}

Gordon P. Eaton, Director

For additional information write to:

Copies of this report can be purchased from:

District Chief

U.S. Geological Survey

2280 Woodale Drive

Mounds View, MN 55112
U.S. Geological Survey

Branch of Information Services

Box 25286

Denver, CO 80225 


\section{Contents}

Abstract ...

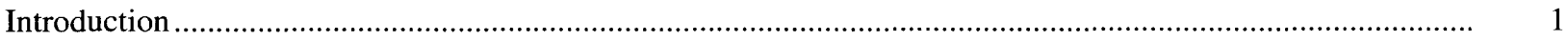

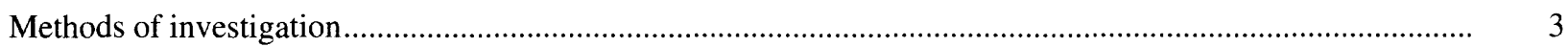

Physical and chemical properties of water

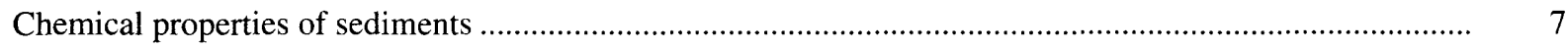

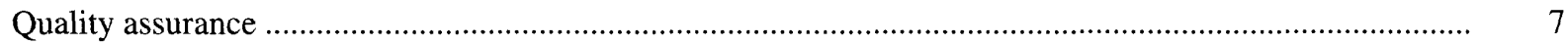

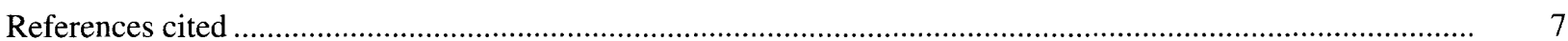

\section{Illustrations}

Figure 1. Map showing location of the study area and data collection sites in the Grand Portage Indian Reservation, northeastern Minnesota....

2. Graph showing vertical profiles of temperature, $\mathrm{pH}$, specific conductance, and dissolved oxygen, Grand Portage and Wauswaugoning Bays, Lake Superior, Grand Portage Indian Reservation, northeastern Minnesota, June 25, 1996

3. Water-quality diagrams of ionic composition for water from Grand Portage and Wauswaugoning Bays, Lake Superior, Grand Portage Indian Reservation, northeastern Minnesota, 1994-95

\section{Tables}

Table 1. Physical and chemical properties and bacterial colony counts in water samples from Grand Portage and Wauswaugoning Bays, Lake Superior, Grand Portage Indian Reservation, northeastern Minnesota, 1993-96.

2. Nutrient and major and minor ion concentrations in water samples from Grand Portage and Wauswaugoning Bays, Lake Superior, Grand Portage Indian Reservation, northeastern Minnesota, 1993-1995.

3. Trace-metal concentrations in water samples from Grand Portage and Wauswaugoning Bays, Lake Superior, Grand Portage Indian Reservation, northeastern Minnesota, 1993-95.

4. Pesticide, phenol, and asbestos concentrations in water samples from Wauswaugoning Bay, Lake Superior, Grand Portage Indian Reservation, northeastern Minnesota, 1995.

5. Trace-metal concentrations in suspended-and bottom-sediment samples from Grand Portage Bay, Grand Portage Indian Reservation, northeastern Minnesota, 1993

\section{Conversion Factors, and Units of Concentration}

\section{Multiply inch-pound unit}

foot (ft)

acre

degree Fahrenheit $\left({ }^{\circ} \mathrm{F}\right)$

$$
\begin{aligned}
& \text { By } \\
& .3048 \\
& 4.047 \times 10^{-3}
\end{aligned}
$$

$\left({ }^{\circ} \mathrm{F}-32\right) / 1.8$
To obtain metric unit meter square kilometer degree Celsius $\left({ }^{\circ} \mathrm{C}\right)$

Concentrations of chemical constituents in water samples are given in milligrams per liter ( $\mathrm{mg} / \mathrm{L})$, micrograms per liter $(\mu \mathrm{g} / \mathrm{L})$, and milliequivalents per liter (meq/L). Milligrams per liter is a unit that expresses the concentration of a chemical constituent in solution as the mass (milligrams) of the constituent per unit volume (liter) of water. One milligram per 
liter is equivalent to one thousand micrograms per liter. Concentrations of chemical constituents in $\mathrm{mg} / \mathrm{L}$ and $\mu \mathrm{g} / \mathrm{L}$ are reported as: (1) dissolved; (2) total recoverable; and (3) total.

Milliequivalents per liter is a unit that expresses the concentration of chemical constituents in solution as the mass (milligrams) of the constituents per unit volume (liter) of water that combine with each other. One milliequivalent of a chemical constituent has a mass in milligrams that is equal to the sum of the atomic weights of the atoms that comprise the constituent divided by the number of charges normally associated with the constituent. Thus one milliequivalent of $\mathrm{Ca}^{++}$(calcium ion), which has an atomic weight of 40 and a charge of plus two, has a mass of 20 milligrams. In a water sample that has the meq/L of each of the chemical constituents accurately determined, the total meq/L of cations (positive ions) is equal to the total meq/L of anions (negative ions).

Concentrations of trace metals in sediment samples are given in micrograms per gram $(\mu \mathrm{g} / \mathrm{g})$. Micrograms per gram is a unit that expresses the mass (micrograms) of a trace metal per unit mass (gram) of sediment.The concentrations of trace metals in sediment samples are reported as: (1) total recoverable; and (2) total.

\section{Definition of Terms}

Alkalinity: Capacity for neutralizing acid and commonly reported as an equivalent amount of calcium carbonate. This property is attributed mostly to dissolved species of carbon dioxide if the $\mathrm{pH}$ of the water is less than 9.5.

Dissolved: Refers to the portion of a given chemical constituent in solution that passes through a 0.45 -micrometer membrane filter.

Dissolved solids concentration: Total amount of chemical constituents dissolved in the water and is expressed in $\mathrm{mg} / \mathrm{L}$.

Fecal coliform bacteria: Bacteria that are present in the intestines and feces of warm-blooded animals.

Fecal streptococcal bacteria: Bacteria that are present in the intestines of warmblooded animals.

Pesticide: A general term for chemicals, which include herbicides, insecticides, and fungicides, that are used to control crop pests.

$p H$ : A measure of the acidity (or alkalinity) of a solution; equal to the negative logarithm of the concentration of hydrogen ions. A pH of 7.0 indicates a neutral solution, a pH value lower than 7.0 indicates an acid solution, and a $\mathrm{pH}$ values greater than 7.0 indicates an alkaline solution.

Secchi disk transparency: The maximum depth below the surface of water that a white disk about 20 centimeters in diameter is visible.

Sediment: Solid material that includes disintegrated rock particles, chemical and biochemical precipitates and decomposed organic material. In a lake, it may be bottom sediment below the water column in unconsolidated lakebed material, or suspended sediment within the water column.

Specific conductance: The capacity of water to conduct an electric current. This property generally is proportionate to the dissolved solids content in most dilute natural water.

Suspended: Refers to the portion of a given chemical constituent in solution that does not pass through a $0.45-$ micrometer membrane filter.

Suspended-solids concentration: Total amount of chemical constituents suspended in the water and is expressed in $\mathrm{mg} / \mathrm{L}$.

Total: Refers to the amount of a given constituent in an unfiltered water or sediment sample after digestion by a method (usually by a dilute acid solution) that results in dissolution of at least 95 percent of the constituent that was in the sample.

Total recoverable: Refers to the amount of a given constituent in an unfiltered water or sediment sample after digestion by a method (usually by a dilute acid solution) that results in dissolution of less than 95 percent of the constituent that was in the sample.

Turbidity: Inversely related to water clarity; a measure of suspended particulate matter. 


\title{
Physical and Chemical Properties of Water and Sediments, Grand Portage and
}

\author{
Wauswaugoning Bays, Lake Superior, Grand Portage Indian Reservation,
}

\author{
Northeastern Minnesota, 1993-96
}

\author{
By James F. Ruhl
}

\begin{abstract}
This report is a compilation of data on the physical and chemical properties of water and sediments in Grand Portage and Wauswaugoning Bays of Lake Superior along the shoreline of the Grand Portage Indian Reservation. The data were collected during 1993-96 by the U.S. Geological Survey in cooperation with the Grand Portage Indian Reservation. The data include: (1) temperature, $\mathrm{pH}$, and specific conductance measurements and dissolved oxygen concentrations; (2) Secchi disk transparency, alkalinity, and turbidity measurements; (3) fecal Coliform and fecal Streptococcal bacteria colony counts (per 100 milliliters of sample water); (4) major and minor ion, nutrient, and trace-metal concentrations; (5) dissolved and suspended residue concentrations; (6) pesticide, phenol, and asbestos concentrations; (7) suspended sediment trace-metal concentrations; and (8) bottom sediment trace-metal concentrations. Water samples were collected from nine sites; suspended and bottom sediment samples were collected from five sites. The data in this report can be used to evaluate present water-quality conditions and as a reference to monitor potential long-term changes in these conditions.
\end{abstract}

\section{Introduction}

The Grand Portage Indian Reservation (hereinafter referred to as the Reservation) is located in extreme northeastern Minnesota along the north shore of Lake Superior (fig. 1). The Reservation has an area of about 56,000 acres and is mostly forest. Total population of the Reservation is about 350 people (Rick Novitsky, Grand Portage Indian Reservation Tribal Council, oral commun., 1994). Most homes, businesses, tourist and historical attractions, are located in the community of Grand Portage, along U.S. Highway 61, and east of Mineral Center along County State Aid Highway 17.

This report provides the Reservation Tribal Council important water-quality information about Grand Portage and Wauswaugoning Bays (fig. 1). The two bays have important aesthetic, fishery, and water-supply values. Grand Portage Bay is a spawning and nursery area for a variety of fish species, which include lake trout, lake whitefish, lake herring, and non-game species. Wauswaugoning Bay is the site of a recently constructed (1996) community water-supply system. The intake for this system is at a depth of about $50 \mathrm{ft}$ (Steve Forthun, Indian Public Health Service, oral commun., 1997) at the southeastern tip of Hat Point (fig. 1).

The purpose of this report is to present data on the physical and chemical properties of water and sediments in Grand Portage and Wauswaugoning Bays of Lake Superior along the shoreline of the Grand Portage Indian Reservation. The data will serve as a reference to monitor potential changes in water quality and sediment chemistry in the bays. The data were collected during 1993-96 from one site in Wauswaugoning Bay and from eight sites in Grand Portage Bay (fig. 1 inset). The data include: (1) temperature, $\mathrm{pH}$, and specific conductance measurements and dissolved oxygen concentrations at eight sites; (2) Secchi disk transparency at one site, alkalinity, and turbidity measurements at three sites; (3) fecal Streptococcal and fecal Coliform bacteria colony counts at six sites; (4) major and minor ion, nutrient, and trace-metal concentrations at three sites; (5) dissolved and suspended residue concentrations at three sites; (6) pesticide, phenol, and asbestos concentrations at one site; (7) suspended sediment trace-metal concentrations at one site; and (8) bottom sediment trace-metal concentrations at four sites. 


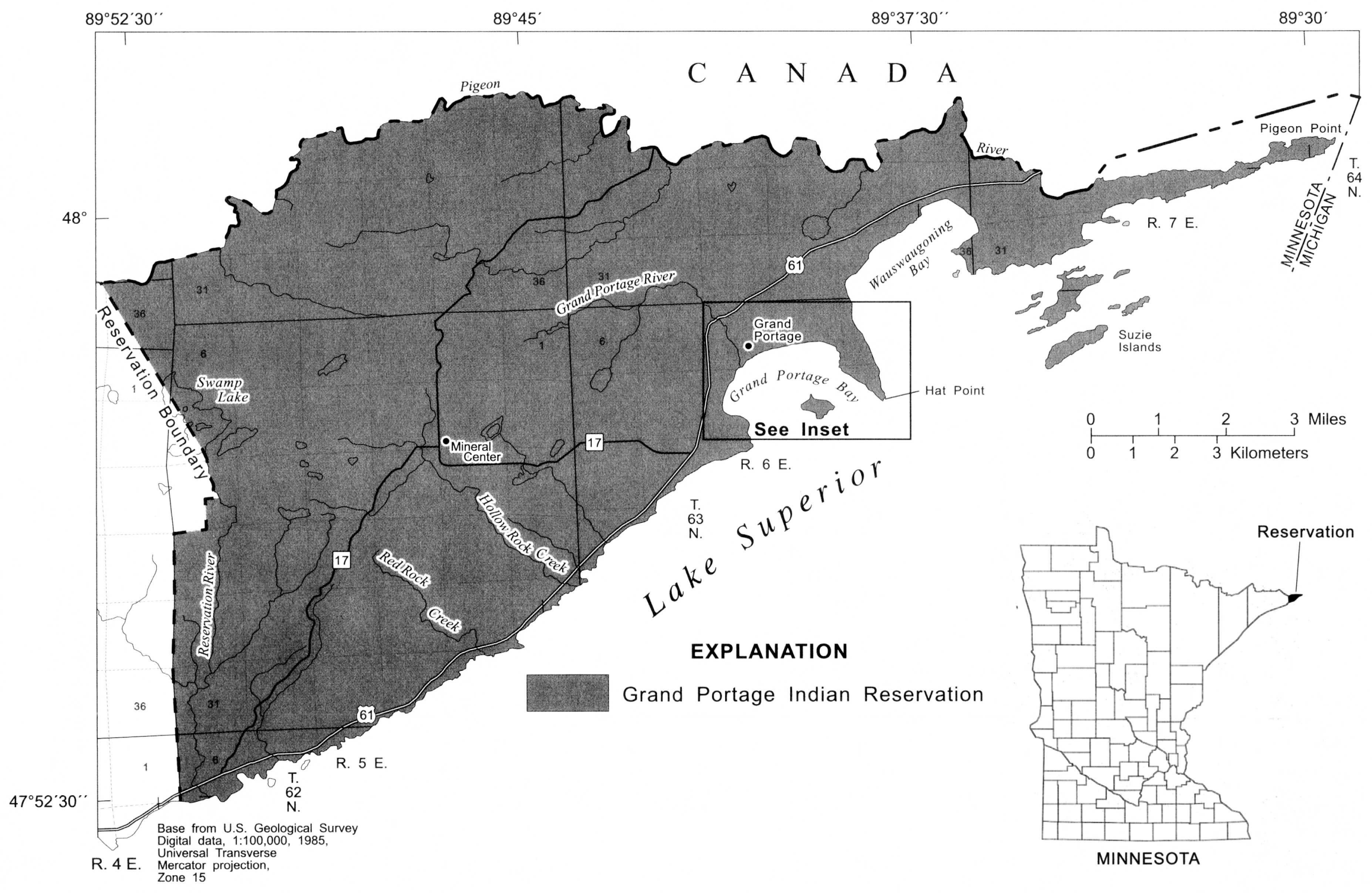

Figure 1. Location of the study area and data collection sites in the Grand Portage Indian Reservation, northeastern Minnesota. 


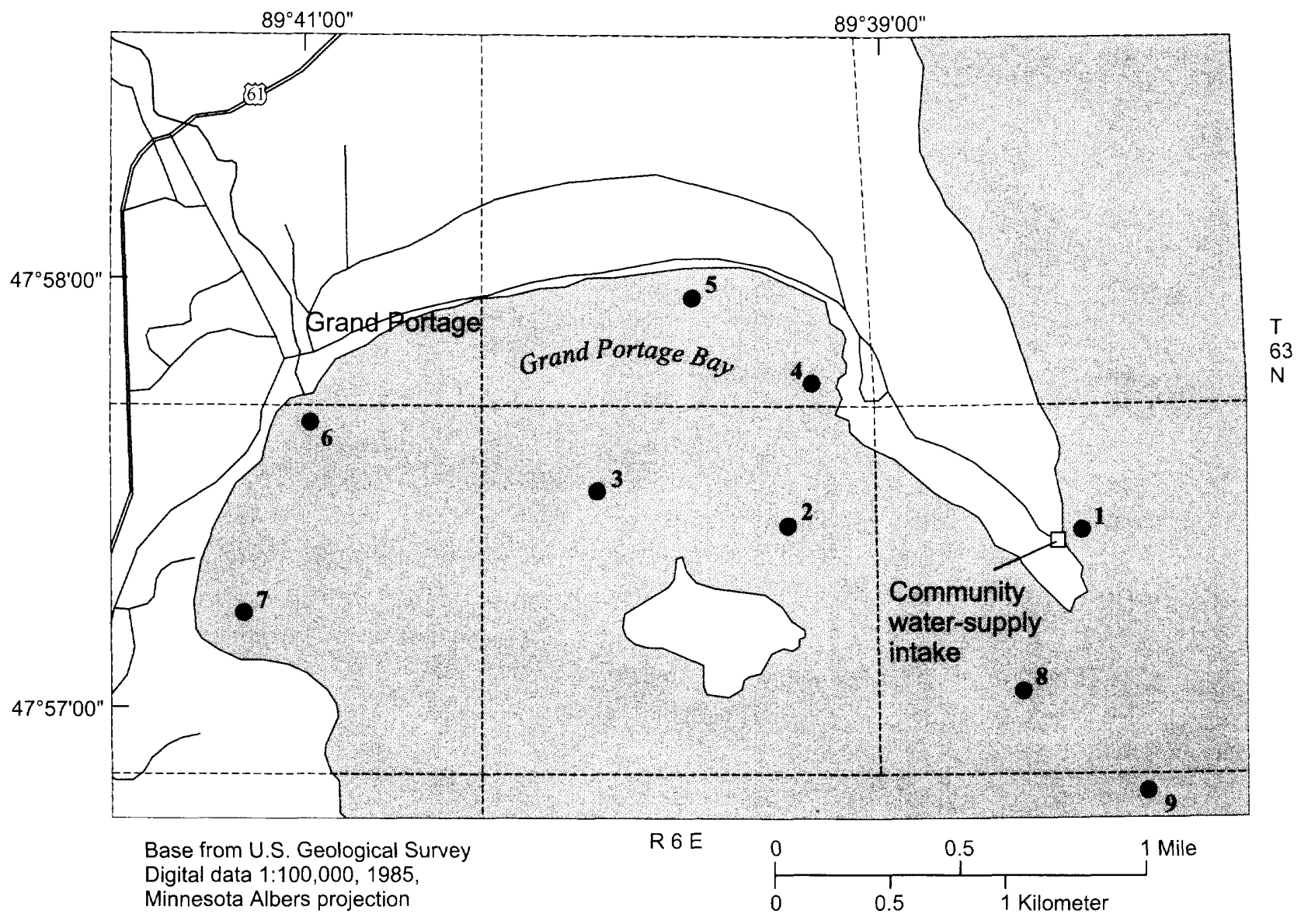

Figure 1 inset.

\section{EXPLANATION}

-1 Data collection site (number is site identifier)

\section{Methods of Investigation}

Water samples were collected, treated, and stored in accordance with procedures described by Fishman and Friedman (1989). Most of the water samples were analyzed for chemical constituents at the U.S. Geological Survey NWQL (National Water Quality Laboratory) in Arvada, Colorado. The asbestos water sample was analyzed by the Reservoirs Environmental Services, Inc. in Denver, Colorado by the U.S. Environmental Protection Agency Level II TEM method (Yamate and others, U.S. Environmental Protections Agency, written commun., 1985).

Suspended-sediment samples were analyzed for trace-metal concentrations by the U.S. Geological Survey Laboratory in Atlanta, Georgia by analytical procedures described by Horowitz (1986). Bottom- sediment samples were collected, treated, and stored in accordance with procedures described by Tanner and others (1990). The bottom-sediment samples were analyzed for trace-metal concentrations at the U.S. Geological Survey NWQL.

\section{Physical and Chemical Properties of Water}

Field measurements of temperature, $\mathrm{pH}$, specific conductance, and dissolved oxygen were made with a portable, multiparameter meter calibrated at the start of each sampling day. Vertical profiles of these measurements were made to depths of $12-80 \mathrm{ft}$ at sites 1 , $2,3,8$, and 9 ; surface measurements ( 1 -ft depth) were made at sites 4,5 , and 6 (table 1). The vertical profiles determined for sites 1, 3, 8, and 9 on June 25, 1996 are graphically shown in figure 2 . 
Table 1. - Physical and chemical properties and bacterial colony counts in water samples from Grand Portage and Wauswaugoning Bays, Lake Superior, Grand Portage Indian Reservation, northeastern Minnesota, 1993-96. $[\mathrm{mg} / \mathrm{L}$, milligrams per liter; $\mathrm{ml}$, milliliter; $\mu \mathrm{S} / \mathrm{cm}$, microsiemens per centimeter;

${ }^{\circ} \mathrm{C}$, degree Celsius;--, no data; $\mathrm{K}$, non-ideal colony count; NTU, nephelometric turbidity units; $\mathrm{CaCO}_{3}$, calcium carbonate]

\begin{tabular}{|c|c|c|c|c|c|c|c|c|c|c|c|c|c|}
\hline $\begin{array}{l}\text { Site } \\
\text { ident- } \\
\text { ifier } \\
\text { for sites } \\
\text { shown } \\
\text { on } \\
\text { figure 1 } \\
\text { inset }\end{array}$ & $\begin{array}{c}\text { Site } \\
\text { identfication } \\
\text { number }\end{array}$ & Date & $\begin{array}{c}\text { Depth at } \\
\text { sample } \\
\text { location, } \\
\text { total } \\
\text { (feet) }\end{array}$ & $\begin{array}{l}\text { Secchi } \\
\text { disk } \\
\text { trans- } \\
\text { parency } \\
\text { (feet) }\end{array}$ & $\begin{array}{c}\text { Sample } \\
\text { depth } \\
\text { (feet) }\end{array}$ & $\begin{array}{l}\text { Temper- } \\
\text { ature, } \\
\text { field } \\
\left({ }^{\circ} \mathrm{C}\right)\end{array}$ & $\begin{array}{c}\mathrm{pH}, \\
\text { field } \\
\text { (standard } \\
\text { units) }\end{array}$ & $\begin{array}{l}\text { Specific } \\
\text { conduct- } \\
\text { ance, } \\
\text { field } \\
(\mu \mathrm{S} / \mathrm{cm})\end{array}$ & $\begin{array}{l}\text { Oxygen, } \\
\text { dissolved, } \\
\text { field } \\
(\mathrm{mg} / \mathrm{L})\end{array}$ & $\begin{array}{l}\text { Alka- } \\
\text { linity, } \\
\text { total, } \\
\text { lab } \\
(\mathrm{mg} / \mathrm{L} \text { as } \\
\left.\mathrm{CaCO}_{3}\right)\end{array}$ & $\begin{array}{c}\text { Turbid- } \\
\text { ity } \\
\text { (NTU) }\end{array}$ & $\begin{array}{c}\text { Coli- } \\
\text { form, } \\
\text { fecal, } \\
\text { bacteria } \\
\text { (colonies } \\
\text { per } \\
100 \mathrm{ml} \text { ) }\end{array}$ & $\begin{array}{c}\text { Strepto- } \\
\text { coccal, } \\
\text { fecal, } \\
\text { bacteria } \\
\text { (colonies } \\
\text { per } \\
100 \mathrm{ml} \text { ) }\end{array}$ \\
\hline \multirow[t]{22}{*}{1} & 475725089381301 & $09-22-94$ & 106 & 36.4 & 1 & 14.0 & 7.9 & 95 & 9.8 & $\overline{44}$ & 0.30 & 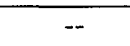 & -- \\
\hline & & & & & 50 & 12.5 & 7.9 & 95 & 10.0 & 44 & .20 & -- & -- \\
\hline & & $08-22-95$ & & - & 1 & 11.0 & 7.6 & 94 & 11.2 & 44 & -- & -- & -- \\
\hline & & & & & 5 & 9.5 & 7.6 & 93 & 11.4 & -- & -- & -- & -- \\
\hline & & & & & 10 & 9.5 & 7.6 & 93 & 11.6 & -- & -- & -- & -- \\
\hline & & & & & 20 & 9.0 & 7.5 & 93 & 11.8 & -- & -- & -- & -- \\
\hline & & & & & 30 & 8.5 & 7.5 & 92 & 12.1 & -- & -- & -- & -- \\
\hline & & & & & 40 & 7.5 & 7.5 & 93 & 12.1 & -- & - & -- & -- \\
\hline & & & & & 50 & 7.0 & 7.5 & 92 & 12.4 & -- & -- & -- & -- \\
\hline & & & & & 60 & 6.0 & 7.4 & 92 & 12.4 & -- & -- & -- & -- \\
\hline & & & & & 70 & 6.0 & 7.4 & 91 & 12.3 & -- & -- & -- & -- \\
\hline & & & & & 80 & 6.0 & 7.4 & 91 & 12.4 & -- & -- & -- & -- \\
\hline & & $06-25-96$ & & 44.9 & 1 & 5.7 & 7.7 & 90 & 12.1 & -- & -- & 0 & 0 \\
\hline & & & & & 5 & 4.3 & 7.6 & 89 & 12.3 & -- & -- & -- & -- \\
\hline & & & & & 10 & 3.8 & 7.6 & 89 & 12.6 & -- & - & -- & -- \\
\hline & & & & & 20 & 3.4 & 7.5 & 88 & 12.7 & -- & -- & -- & -- \\
\hline & & & & & 30 & 3.5 & 7.5 & 89 & 12.8 & -- & -- & -- & - \\
\hline & & & & & 40 & 3.4 & 7.5 & 89 & 12.8 & -- & -- & -- & -- \\
\hline & & & & & 50 & 3.5 & 7.5 & 89 & 12.9 & -- & -- & -- & -- \\
\hline & & & & & 60 & 3.4 & 7.5 & 89 & 13.0 & -- & -- & -- & -- \\
\hline & & & & & 70 & 3.4 & 7.5 & 89 & 13.1 & - & -- & -- & -- \\
\hline & & & & & 80 & 3.5 & 7.5 & 89 & 13.2 & -- & -- & -- & - \\
\hline \multirow[t]{6}{*}{2} & 475728089391501 & $08-16-93$ & 23 & - & 1 & 17.0 & 8.4 & 91 & 9.8 & 42 & .20 & - & - \\
\hline & & & & & 6 & 17.0 & 8.5 & 90 & 9.2 & -- & -- & -- & -- \\
\hline & & & & & 10 & 16.5 & 8.5 & 90 & 9.4 & -- & -- & -- & -- \\
\hline & & & & & 14 & 16.5 & 8.5 & 90 & 9.4 & -- & -- & - & - \\
\hline & & & & & 18 & 16.0 & 8.7 & 91 & 9.4 & -- & -- & -- & - \\
\hline & & & & & 22 & 15.5 & 8.8 & 91 & 10.7 & -- & -- & -- & -- \\
\hline \multirow[t]{8}{*}{3} & 475730089400001 & $08-16-93$ & 14 & -- & 1 & 16.0 & 8.4 & 91 & 9.8 & 43 & .20 & - & - \\
\hline & & & & & 3 & 16.0 & 8.4 & 92 & 9.6 & -- & -- & -- & - \\
\hline & & & & & 5 & 16.0 & 8.4 & 92 & 9.8 & -- & -- & -- & - \\
\hline & & & & & 7 & 15.5 & 8.5 & 92 & 10.0 & -- & -- & -- & - \\
\hline & & & & & 9 & 15.5 & 8.6 & 92 & 9.8 & - & -- & -- & - \\
\hline & & & & & 12 & 15.0 & 8.8 & 92 & 10.1 & - & -- & -- & - \\
\hline & & $09-22-94$ & & -- & 5 & 14.0 & 8.1 & 95 & 10.0 & 45 & .20 & -- & -- \\
\hline & & $08-22-95$ & & -- & 1 & -- & -- & -- & -- & -- & -- & 0 & 0 \\
\hline
\end{tabular}


Table 1.-Physical and chemical properties and bacterial colony counts in water samples from Grand Portage and Wauswaugoning Bays, Lake Superior, Grand Portage Indian Reservation, northeastern Minnesota, 1993-96-continued.

\begin{tabular}{|c|c|c|c|c|c|c|c|c|c|c|c|c|c|}
\hline $\begin{array}{l}\text { Site } \\
\text { ident- } \\
\text { ifier } \\
\text { for sites } \\
\text { shown } \\
\text { on } \\
\text { figure } 1 \\
\text { inset }\end{array}$ & $\begin{array}{c}\text { Site } \\
\text { identfication } \\
\text { number }\end{array}$ & Date & $\begin{array}{c}\text { Depth at } \\
\text { sample } \\
\text { location, } \\
\text { total } \\
\text { (feet) }\end{array}$ & $\begin{array}{l}\text { Secchi } \\
\text { disk } \\
\text { trans- } \\
\text { parency } \\
\text { (feet) }\end{array}$ & $\begin{array}{c}\text { Sample } \\
\text { depth } \\
\text { (feet) }\end{array}$ & $\begin{array}{l}\text { Temper- } \\
\text { ature, } \\
\text { field } \\
\left({ }^{\circ} \mathrm{C}\right)\end{array}$ & $\begin{array}{c}\mathrm{pH}, \\
\text { field } \\
\text { (standard } \\
\text { units) }\end{array}$ & $\begin{array}{c}\text { Specific } \\
\text { conduct- } \\
\text { ance, } \\
\text { field } \\
(\mu \mathrm{S} / \mathrm{cm})\end{array}$ & $\begin{array}{l}\text { Oxygen, } \\
\text { dissolved, } \\
\text { field } \\
(\mathrm{mg} / \mathrm{L})\end{array}$ & $\begin{array}{l}\text { Alka- } \\
\text { linity, } \\
\text { total, } \\
\text { lab } \\
\text { (mg/L as } \\
\left.\mathrm{CaCO}_{3}\right)\end{array}$ & $\begin{array}{l}\text { Turbid- } \\
\text { ity } \\
\text { (NTU) }\end{array}$ & $\begin{array}{c}\text { Coli- } \\
\text { form, } \\
\text { fecal, } \\
\text { bacteria } \\
\text { (colonies } \\
\text { per } \\
100 \mathrm{ml} \text { ) }\end{array}$ & $\begin{array}{c}\text { Strepto- } \\
\text { coccal, } \\
\text { fecal, } \\
\text { bacteria } \\
\text { (colonies } \\
\text { per } \\
100 \mathrm{ml} \text { ) }\end{array}$ \\
\hline & & $06-25-96$ & & -- & 1 & 5.5 & 7.6 & 90 & 12.4 & -- & -- & -- & - \\
\hline & & & & & 5 & 5.5 & 7.6 & 90 & 12.5 & -- & -- & -- & -- \\
\hline & & & & & 10 & 5.0 & 7.6 & 89 & 12.6 & -- & -- & -- & -- \\
\hline & & & & & 14 & 5.0 & 7.6 & 89 & 12.7 & -- & -- & -- & -- \\
\hline \multirow[t]{2}{*}{4} & 475745089391501 & $08-22-95$ & 10 & -- & 1 & -- & -- & -- & -- & -- & -- & 0 & K5 \\
\hline & & $06-25-96$ & & -- & 1 & 5.5 & 7.6 & 90 & 12.4 & -- & -- & -- & -- \\
\hline 5 & 475757089394001 & $06-25-96$ & 10 & -- & 1 & 5.5 & 7.6 & 90 & 12.4 & -- & -- & 0 & 0 \\
\hline \multirow[t]{2}{*}{6} & 475740089410001 & $09-22-94$ & 10 & -- & 1 & -- & -- & -- & -- & -- & -- & K7 & 29 \\
\hline & & $06-25-96$ & & -- & 1 & 5.5 & 7.6 & 90 & 12.4 & -- & -- & 0 & 0 \\
\hline \multirow[t]{2}{*}{7} & 475710089412001 & $09-22-94$ & 10 & -- & 1 & -- & -- & -- & -- & -- & -- & $\mathrm{K} 4$ & $\mathrm{~K} 10$ \\
\hline & & $06-25-96$ & & -- & 1 & -- & -- & -- & -- & -- & -- & 0 & $\mathrm{~K} 1$ \\
\hline \multirow[t]{10}{*}{8} & 475702089383101 & $06-25-96$ & -- & -- & 1 & 2.9 & 7.6 & 89 & 12.5 & -- & -- & - & -- \\
\hline & & & & & 5 & 2.8 & 7.5 & 89 & 12.4 & -- & -- & -- & -- \\
\hline & & & & & 10 & 2.8 & 7.5 & 89 & 12.3 & -- & -- & -- & - \\
\hline & & & & & 20 & 2.8 & 7.4 & 89 & 12.4 & -- & -- & -- & -- \\
\hline & & & & & 30 & 2.8 & 7.4 & 89 & 12.4 & -- & -- & -- & -- \\
\hline & & & & & 40 & 2.8 & 7.4 & 89 & 12.5 & -- & -- & -- & -- \\
\hline & & & & & 50 & 2.8 & 7.4 & 89 & 12.4 & -- & -- & -- & -- \\
\hline & & & & & 60 & 2.8 & 7.4 & 89 & 12.4 & -- & -- & -- & -- \\
\hline & & & & & 70 & 2.9 & 7.4 & 89 & 12.3 & -- & -- & -- & -- \\
\hline & & & & & 80 & 2.9 & 7.4 & 89 & 12.1 & -- & -- & -- & -- \\
\hline \multirow[t]{10}{*}{9} & 475648089380501 & $06-25-96$ & -- & -- & 1 & 2.9 & 7.7 & 89 & 13.4 & -- & -- & -- & -- \\
\hline & & & & & 5 & 2.8 & 7.6 & 89 & 12.7 & -- & -- & -- & -- \\
\hline & & & & & 10 & 2.7 & 7.5 & 89 & 12.7 & - & -- & - & -- \\
\hline & & & & & 20 & 2.7 & 7.5 & 89 & 12.6 & -- & -- & -- & -- \\
\hline & & & & & 30 & 2.7 & 7.5 & 89 & 12.7 & -- & -- & -- & -- \\
\hline & & & & & 40 & 2.7 & 7.5 & 89 & 12.7 & -- & -- & -- & -- \\
\hline & & & & & 50 & 2.7 & 7.4 & 89 & 12.8 & -- & -- & -- & -- \\
\hline & & & & & 60 & 2.7 & 7.4 & 89 & 12.9 & -- & -- & -- & -- \\
\hline & & & & & 70 & 2.7 & 7.4 & 89 & 13.0 & -- & -- & -- & -- \\
\hline & & & & & 80 & 2.7 & 7.4 & 89 & 13.0 & -- & -- & -- & -- \\
\hline
\end{tabular}



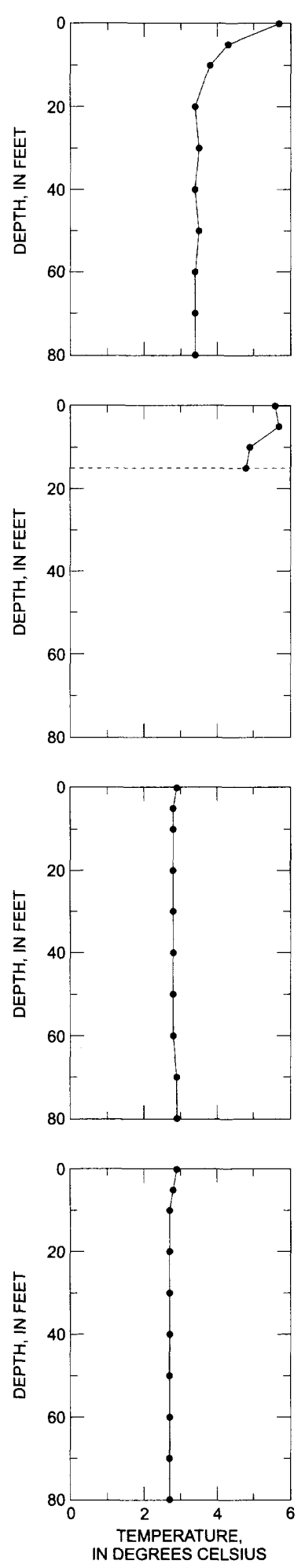

SITE 1
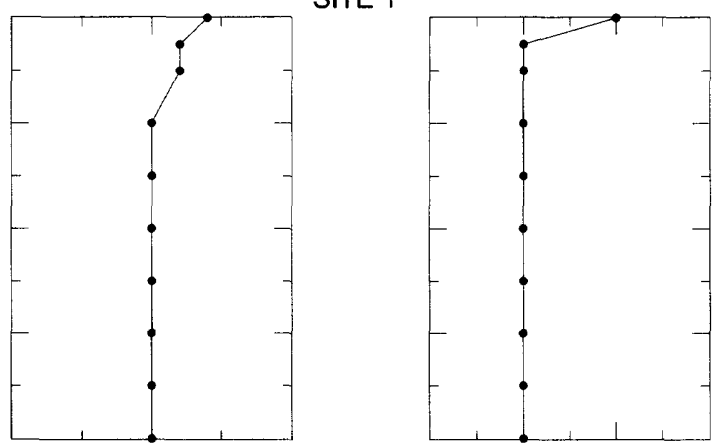

SITE 3
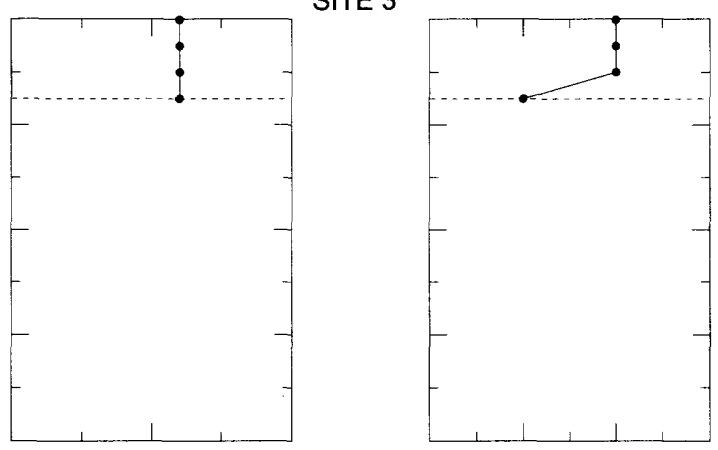

SITE 8
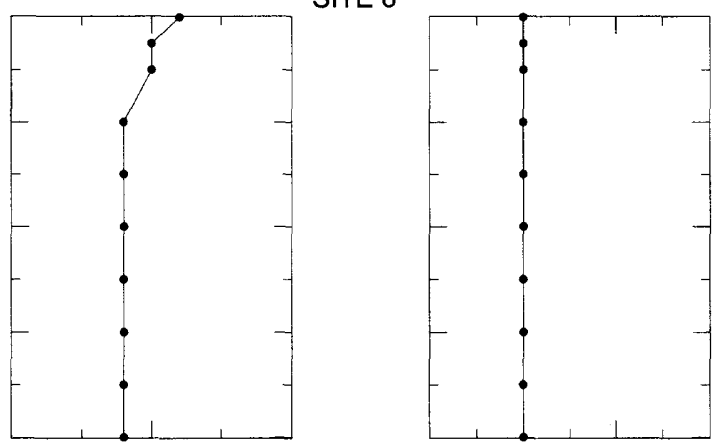

SITE 9
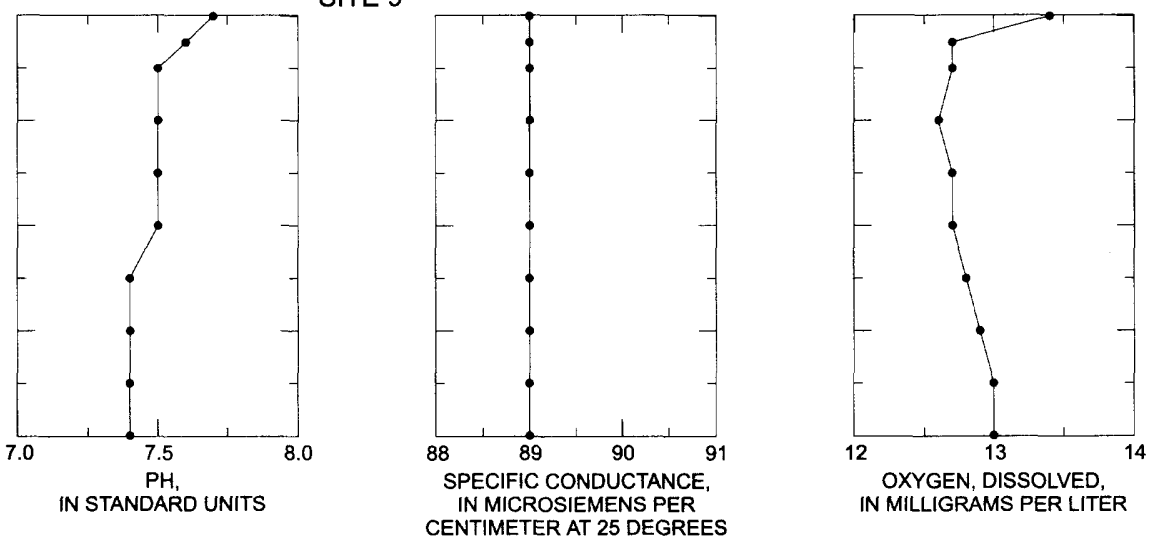

\section{EXPLANATION}

$\longrightarrow$ Dot indicates field measurement

Bay bottom
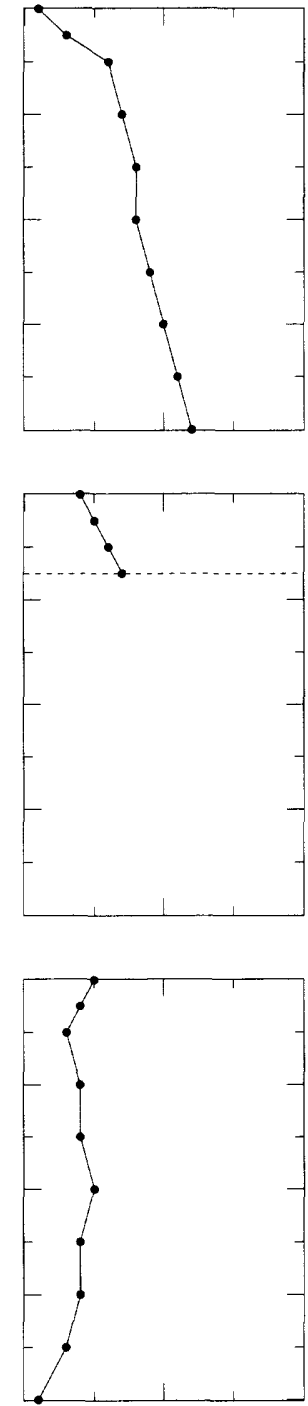

IN MILLIGRAMS PER LITER

Figure 2. Vertical profiles of temperature, pH, specific conductance, and dissolved oxygen, Grand Portage and Wauswaugoning Bays, Lake Superior, Grand Portage Indian Reservation, northeastern Minnesota, June 25, 1996 (sites shown on figure 1). 
The Secchi disk transparency was measured at site 1 (table 1). Turbidity and alkalinity were determined for samples collected from sites 1,2, and 3 (table 1).

Colony counts (reported per $100 \mathrm{ml}$ of sample water) of fecal Coliform and fecal Streptococcal bacteria were determined for surface samples ( 1 -ft depth) from sites 1 , $3,4,5,6$, and 7 . The colony counts were made on membrane filters inoculated with unfiltered sample water serially diluted with sterile, buffered water. The sample water was serially diluted to grow ideal colony counts of 20 to 60 per filter. The colony counts were made after the filters had been incubated in petri dishes half-filled with bacterial growth media. The incubation periods were 24 hours at $35^{\circ} \mathrm{C}$ for fecal Coliform bacteria and 48 hours at $44.5^{\circ} \mathrm{C}$ for fecal Streptococcal bacteria.

Water samples were collected from multiple depths with a poly-carbonate, fixed-point sampler at sites 1,2, and 3 . These samples were analyzed for major and minor ions, nutrients, dissolved and suspended residue, and trace metals (tables 2 and 3). The concentrations (in $\mathrm{mg} / \mathrm{L}$ and $\mu \mathrm{g} / \mathrm{L}$ ) of the constituents are reported as dissolved, total recoverable, and total.

The residue on evaporation was determined for filtered water samples at $180^{\circ} \mathrm{C}$ for sites 1 and 3 and at $105^{\circ} \mathrm{C}$ for sites 2 and 3 . These residues represent analytical determinations of the dissolved solids concentration in the water samples. (The residue on evaporation at $105^{\circ} \mathrm{C}$ may be slightly larger than for $180^{\circ} \mathrm{C}$ because dissolved organic carbon remains in the residue at $105^{\circ} \mathrm{C}$, whereas dissolved organic carbon does not remain in the residue at $180^{\circ} \mathrm{C}$.) The residue on evaporation also was determined for the filters at $105^{\circ} \mathrm{C}$ for sites 2 and 3 . These residues represent analytical determinations of the supsended solids concentration in the water samples.

The ionic compositions (in meq/L) of water samples from sites 1 and 3 are shown on water-quality diagrams (fig. 3). These diagrams graphically indicate the amounts and proportions of ionic solutes in the samples.

The laboratory analytical reporting limits (minimum concentrations that can be reliably cited) for the major and minor ions and nutrients were 0.01 and $0.02 \mathrm{mg} / \mathrm{L}$. The laboratory analytical reporting limits for trace metals ranged from 0.5 to $10 \mu \mathrm{g} / \mathrm{L}$ except for the limit of $100 \mu \mathrm{g} / \mathrm{L}$ for barium. Constituents that were present at a concentration less than the reporting limit are reported as $<$ (less than) the reporting limit.

Water from depths of 1 and 50 feet at site 1 was analyzed for about 50 pesticides, phenols, and asbestos (table 4). The pesticide classes were mostly triazines, acidimides, acetanilides, organophosphates, organochlorines, and carbamates and to a lesser extent anilines, urea, uracil, and chlorobenzoic acid. The pesticide analyses were done by GC/MS (gas chromatography/mass spectrometry) at the U.S. Geological Survey NWQL. Analytical reporting limits were 0.001 to $0.018 \mu \mathrm{g} / \mathrm{L}$ for the pesticides, $1 \mu \mathrm{g} / \mathrm{L}$ for phenols, and 0.05 structures/L for asbestos.

\section{Chemical Properties of Sediments}

A 150-liter unfiltered water sample from site 3 was analyzed for trace metal-concentrations of the suspended sediments. The water sample was collected by depth integration from the top to the bottom of the lake (14-ft water column). The suspended sediments were removed from the sample by centrifugation; the settled solid material was then freeze-dried and digested by an acid solution for chemical analysis. The results are reported as total trace-metal concentrations in suspended sediments (table 5).

Bottom sediments from sites 4, 5, 6, and 7 were analyzed for trace-metal concentrations. The samples were collected with a dredge sampler. The results are reported in table 5 as total and total recoverable tracemetal concentrations in bottom sediments.

\section{Quality Assurance}

Blank-water and replicate samples were analyzed for nitrogen and phosphorus nutrients and major and minor ions to verify quality assurance of the analytical results reported by the U.S. Geological Survey NWQL. The blank and replicate samples were subjected to the same processing, handling, and equipment as sample water. The quality-assurance analyses indicated that samples were not cross-contaminated by equipment between visits to sample sites and that analytical results for water samples reported by the U.S. Geological Survey NWQL were reproducible to within 5 percent of each other.

\section{References Cited}

Fishman, M.J., and Friedman, L.C., 1989, Methods for the determination of inorganic substances in water and fluvial sediments: U.S. Geological Survey Techniques of Water-Resources Investigations, book 5, chap. A1, 545 p.

Horowitz, A.J., 1986, Comparison of methods for the concentration of suspended sediment in river water for subsequent chemical analysis: Environmental Science and Technology, v. 20, no. 2, p. 155-160.

Tanner, D.Q., Sanzolone, R.F., and Zelt, R.B., 1990, Surface-waterquality assessment of the lower Kansas River Basin, Kansas and Nebraska--Concentrations of major metals and trace elements in streambed sediments, 1987: U.S. Geological Survey Open-File Report 90-581, 73 p. 
Table 2.-Nutrient and major and minor ion concentrations in water samples from Grand Portage and Wauswaugoning Bays, Lake Superior, Grand Portage Indian Reservation, northeastern Minnesota, 1993-1995. [mg/L, milligrams per liter; <, less than; --, no data]

\begin{tabular}{|c|c|c|c|c|c|c|c|c|c|c|c|}
\hline $\begin{array}{c}\text { Site } \\
\text { identifier } \\
\text { for sites } \\
\text { shown on } \\
\text { figure } 1 \\
\text { inset }\end{array}$ & Date & $\begin{array}{c}\text { Depth } \\
\text { at sample } \\
\text { location, } \\
\text { total } \\
\text { (feet) }\end{array}$ & $\begin{array}{c}\text { Sampling } \\
\text { depth } \\
\text { (feet) }\end{array}$ & $\begin{array}{l}\text { Nitrogen, } \\
\text { nitrite, } \\
\text { dissolved } \\
\text { (mg/L as } \\
\mathrm{N})\end{array}$ & $\begin{array}{c}\text { Nitrogen, } \\
\text { nitrite }+ \\
\text { nitrate, } \\
\text { dissolved } \\
\text { (mg/L as } \\
\mathrm{N})\end{array}$ & $\begin{array}{l}\text { Nitrogen, } \\
\text { ammonia, } \\
\text { dissolved } \\
(\mathrm{mg} / \mathrm{L} \text { as } \\
\mathrm{N})\end{array}$ & $\begin{array}{l}\text { Nitrogen, } \\
\text { ammonia + } \\
\text { organic, } \\
\text { dissolved, } \\
(\mathrm{mg} / \mathrm{L} \text { as } \\
\mathrm{N})\end{array}$ & $\begin{array}{c}\text { Phosphorus, } \\
\text { total } \\
\text { (mg/L as } \\
\mathrm{P})\end{array}$ & $\begin{array}{l}\text { Phosphorus, } \\
\text { dissolved } \\
\text { (mg/L as } \\
\text { P) }\end{array}$ & $\begin{array}{c}\text { Phosphorus, } \\
\text { ortho, } \\
\text { dissolved } \\
(\mathrm{mg} / \mathrm{L} \text { as } \\
\left.\mathrm{PO}_{4}\right)\end{array}$ & $\begin{array}{l}\text { Carbon, } \\
\text { organic, } \\
\text { total } \\
(\mathrm{mg} / \mathrm{L} \text { as } \\
\text { C) }\end{array}$ \\
\hline \multirow[t]{3}{*}{1} & $09-22-94$ & 106 & 5.0 & $<0.01$ & 0.28 & $<0.01$ & -- & $<0.01$ & $<0.02$ & $<0.01$ & -- \\
\hline & $09-22-94$ & 106 & 50 & $<.01$ & .30 & $<.01$ & -- & $<.01$ & .01 & $<.01$ & -- \\
\hline & $08-22-95$ & 106 & 50 & $<.01$ & .30 & $<.02$ & -- & $<.01$ & $<.01$ & $<.01$ & 1.8 \\
\hline 2 & $08-16-93$ & 23 & 1.0 & $<.01$ & .28 & .03 & $<0.20$ & $<.01$ & $<.01$ & $<.01$ & -- \\
\hline \multirow[t]{2}{*}{3} & $08-16-93$ & 14 & 1.0 & $<.01$ & .28 & .03 & $<.20$ & $<.01$ & $<.01$ & $<.01$ & -- \\
\hline & $09-22-94$ & 14 & 5.0 & $<.01$ & .27 & $<.01$ & -- & $<.01$ & $<.01$ & $<.01$ & -- \\
\hline
\end{tabular}

\begin{tabular}{|c|c|c|c|c|c|c|c|c|c|c|c|c|c|}
\hline $\begin{array}{c}\text { Site } \\
\text { identifier } \\
\text { shown on } \\
\text { figure } 1 \\
\text { inset }\end{array}$ & Date & $\begin{array}{l}\text { Calcium, } \\
\text { dissolved } \\
(\mathrm{mg} / \mathrm{L} \text { as } \\
\text { Ca })\end{array}$ & $\begin{array}{c}\text { Magnesium, } \\
\text { dissolved } \\
(\mathrm{mg} / \mathrm{L} \text { as } \\
\mathrm{Mg})\end{array}$ & $\begin{array}{l}\text { Sodium, } \\
\text { dissolved } \\
(\mathrm{mg} / \mathrm{L} \text { as } \\
\mathrm{Na})\end{array}$ & $\begin{array}{c}\text { Potassium, } \\
\text { dissolved } \\
(\mathrm{mg} / \mathrm{L} \text { as } \\
\mathrm{K})\end{array}$ & $\begin{array}{c}\text { Sulfate, } \\
\text { dissolved } \\
(\mathrm{mg} / \mathrm{L} \text { as } \\
\left.\mathrm{SO}_{4}\right)\end{array}$ & $\begin{array}{l}\text { Chloride, } \\
\text { dissolved } \\
(\mathrm{mg} / \mathrm{L} \text { as } \\
\mathrm{Cl})\end{array}$ & $\begin{array}{c}\text { Fluoride, } \\
\text { dissolved } \\
(\mathrm{mg} / \mathrm{L} \text { as } \\
\text { F) }\end{array}$ & $\begin{array}{c}\text { Bromide, } \\
\text { dissolved } \\
(\mathrm{mg} / \mathrm{L} \text { as } \\
\mathrm{Br})\end{array}$ & $\begin{array}{c}\text { Silica, } \\
\text { dissolved } \\
(\mathrm{mg} / \mathrm{L} \text { as } \\
\left.\mathrm{SiO}_{2}\right)\end{array}$ & $\begin{array}{c}\text { Residue at } \\
180 \\
\text { degrees } \\
\text { Celsius, } \\
\text { dissolved } \\
(\mathrm{mg} / \mathrm{L})\end{array}$ & $\begin{array}{c}\text { Residue at } \\
105 \\
\text { degrees } \\
\text { Celsius, } \\
\text { dissolved } \\
\text { (mg/L) }\end{array}$ & $\begin{array}{c}\text { Residue at } \\
105 \\
\text { degrees } \\
\text { Celsius, } \\
\text { suspended } \\
(\mathrm{mg} / \mathrm{L})\end{array}$ \\
\hline \multirow[t]{3}{*}{1} & $09-22-94$ & 14 & 3.0 & 1.4 & 0.50 & 3.1 & 1.4 & $<0.10$ & $<0.01$ & 2.3 & 59 & -- & -- \\
\hline & $09-22-94$ & 14 & 3.0 & 1.4 & .50 & 3.1 & 1.4 & $<.10$ & $<.01$ & 2.3 & 59 & -- & -- \\
\hline & $08-22-95$ & 13 & 2.7 & 1.4 & .50 & 3.1 & 1.5 & $<.10$ & $<.01$ & 2.4 & 48 & -- & -- \\
\hline 2 & $08-16-93$ & 14 & 2.7 & 1.4 & -- & 3.4 & 1.5 & $<.10$ & - & 2.3 & -- & 61 & 1 \\
\hline \multirow[t]{2}{*}{3} & $08-16-93$ & 15 & 2.7 & 1.4 & -- & 3.5 & 1.5 & $<.10$ & -- & 2.2 & -- & 66 & 1 \\
\hline & $09-22-94$ & 15 & 3.0 & 1.5 & .50 & 3.1 & 1.4 & $<.10$ & $<.01$ & 2.3 & 62 & -- & -- \\
\hline
\end{tabular}


Table 3. - Trace-metal concentrations in water samples from Grand Portage and

Wauswaugoning Bays, Lake Superior, Grand Portage Indian Reservation, northeastern Minnesota, 1993-95.

[concentrations are in micrograms per liter; <, less than; --, no data]

\begin{tabular}{|c|c|c|c|c|c|c|c|c|c|c|c|c|c|c|}
\hline $\begin{array}{c}\text { Site } \\
\text { identifier } \\
\text { for sites } \\
\text { shown on } \\
\text { figure } 1 \\
\text { inset }\end{array}$ & Date & $\begin{array}{c}\text { Depth } \\
\text { at sample } \\
\text { location, } \\
\text { total } \\
\text { (feet) }\end{array}$ & $\begin{array}{c}\text { Sampling } \\
\text { depth } \\
\text { (feet) }\end{array}$ & $\begin{array}{l}\text { Aluminum, } \\
\text { dissolved }\end{array}$ & $\begin{array}{l}\text { Aluminum, } \\
\text { total } \\
\text { recover- } \\
\text { able }\end{array}$ & $\begin{array}{l}\text { Antimony, } \\
\text { dissolved }\end{array}$ & $\begin{array}{l}\text { Antimony, } \\
\text { total }\end{array}$ & $\begin{array}{l}\text { Arsenic, } \\
\text { dissolved }\end{array}$ & $\begin{array}{l}\text { Arsenic } \\
\text { total }\end{array}$ & $\begin{array}{l}\text { Barium, } \\
\text { dissolved }\end{array}$ & $\begin{array}{l}\text { Barium, } \\
\text { total } \\
\text { recover- } \\
\text { able }\end{array}$ & $\begin{array}{l}\text { Beryllium, } \\
\text { dissolved }\end{array}$ & $\begin{array}{l}\text { Beryllium, } \\
\text { total } \\
\text { recover- } \\
\text { able }\end{array}$ & $\begin{array}{l}\text { Boron, } \\
\text { dissolved }\end{array}$ \\
\hline \multirow[t]{3}{*}{1} & $09-22-94$ & 106 & 5.0 & -- & $<10$ & -- & -- & -- & 1 & -- & $<100$ & -- & $<10$ & -- \\
\hline & $09-22-94$ & 106 & 50 & -- & $<10$ & -- & -- & -- & 1 & -- & $<100$ & -- & $<10$ & -- \\
\hline & $08-22-95$ & 106 & 50 & $<10$ & -- & $<1$ & -- & $<1$ & -- & 10 & -- & $<0.5$ & -- & -- \\
\hline 2 & $08-16-93$ & 23 & 1.0 & $<10$ & $<10$ & $<1$ & $<1$ & $<1$ & $<1$ & 9 & $<100$ & $<.5$ & $<10$ & $<10$ \\
\hline \multirow[t]{2}{*}{3} & 08-16-93 & 14 & 1.0 & $<10$ & $<10$ & $<1$ & $<1$ & $<1$ & $<1$ & 10 & $<100$ & $<.5$ & $<10$ & $<10$ \\
\hline & $09-22-94$ & 14 & 5.0 & -- & $<10$ & -- & -- & -- & 1 & -- & $<100$ & -- & $<10$ & -- \\
\hline
\end{tabular}

\begin{tabular}{|c|c|c|c|c|c|c|c|c|c|c|c|c|c|c|}
\hline $\begin{array}{c}\text { Site } \\
\text { identifier } \\
\text { shown on } \\
\text { figure } 1 \\
\text { inset }\end{array}$ & Date & $\begin{array}{l}\text { Cadmium, } \\
\text { dissolved }\end{array}$ & $\begin{array}{l}\text { Cadmium, } \\
\text { total } \\
\text { recover- } \\
\text { able }\end{array}$ & $\begin{array}{l}\text { Chromium, } \\
\text { dissolved }\end{array}$ & $\begin{array}{l}\text { Chromium, } \\
\text { total } \\
\text { recover- } \\
\text { able }\end{array}$ & $\begin{array}{l}\text { Cobalt, } \\
\text { dissolved }\end{array}$ & $\begin{array}{l}\text { Cobalt, } \\
\text { total } \\
\text { recover- } \\
\text { able }\end{array}$ & $\begin{array}{l}\text { Copper, } \\
\text { dissolved }\end{array}$ & $\begin{array}{l}\text { Copper, } \\
\text { total } \\
\text { recover- } \\
\text { able }\end{array}$ & $\begin{array}{c}\text { Iron, } \\
\text { dissolved }\end{array}$ & $\begin{array}{l}\text { Iron, } \\
\text { total } \\
\text { recover- } \\
\text { able }\end{array}$ & $\begin{array}{c}\text { Lead, } \\
\text { dissolved }\end{array}$ & $\begin{array}{c}\text { Lead, } \\
\text { total } \\
\text { recover- } \\
\text { able }\end{array}$ & $\begin{array}{l}\text { Lithium, } \\
\text { dissolved }\end{array}$ \\
\hline \multirow[t]{3}{*}{1} & $09-22-94$ & -- & $<1$ & -- & $<1$ & -- & $<1$ & -- & 3 & $<3$ & $<10$ & -- & $<1$ & -- \\
\hline & $09-22-94$ & -- & $<1$ & -- & $<1$ & -- & $<1$ & -- & 3 & $<3$ & 20 & -- & $<1$ & -- \\
\hline & $08-22-95$ & $<1$ & -- & $<1$ & -- & $<1$ & -- & 1 & -- & 3 & -- & $<1$ & -- & $<4$ \\
\hline 2 & $08-16-93$ & $<1$ & $<1$ & -- & $<1$ & $<3$ & $<1$ & 2 & 1 & 4 & 30 & $<1$ & $<1$ & $<4$ \\
\hline \multirow[t]{2}{*}{3} & $08-16-93$ & $<1$ & $<1$ & -- & $<1$ & $<3$ & $<1$ & 2 & 1 & 11 & 40 & 5 & $<1$ & $<4$ \\
\hline & $09-22-94$ & -- & $<1$ &.- & $<1$ & -- & $<1$ & -- & 2 & $<3$ & 20 & -- & $<1$ & -- \\
\hline
\end{tabular}


Table 3.- Trace-metal concentrations in water samples from Grand Portage and

Wauswaugoning Bays, Lake Superior, Grand Portage Indian Reservation, northeastern Minnesota, 1993-95-continued.

\begin{tabular}{|c|c|c|c|c|c|c|c|c|c|c|c|c|c|}
\hline $\begin{array}{c}\text { Site } \\
\text { identifier } \\
\text { shown on } \\
\text { figure } 1 \\
\text { inset }\end{array}$ & Date & $\begin{array}{c}\text { Manganese, } \\
\text { dissolved }\end{array}$ & $\begin{array}{c}\text { Manganese, } \\
\text { total } \\
\text { recover- } \\
\text { able }\end{array}$ & $\begin{array}{l}\text { Mercury, } \\
\text { dissolved }\end{array}$ & $\begin{array}{l}\text { Mercury, } \\
\text { total } \\
\text { recover- } \\
\text { able }\end{array}$ & $\begin{array}{l}\text { Molyb- } \\
\text { denum, } \\
\text { dissolved }\end{array}$ & $\begin{array}{l}\text { Molyb- } \\
\text { denum, } \\
\text { total } \\
\text { recover- } \\
\text { able }\end{array}$ & $\begin{array}{l}\text { Nickel, } \\
\text { dissolved }\end{array}$ & $\begin{array}{l}\text { Nickel, } \\
\text { total } \\
\text { recover- } \\
\text { able }\end{array}$ & $\begin{array}{l}\text { Selenium, } \\
\text { dissolved }\end{array}$ & $\begin{array}{l}\text { Selenium, } \\
\text { total }\end{array}$ & $\begin{array}{c}\text { Silver, } \\
\text { dissolved }\end{array}$ & $\begin{array}{l}\text { Silver, } \\
\text { total } \\
\text { recover- } \\
\text { able }\end{array}$ \\
\hline \multirow[t]{3}{*}{1} & $09-22-94$ & $<1$ & $<10$ & -- & 0.70 & -- & $<1$ & - & 2 & -- & $<1$ & -- & $<1$ \\
\hline & $09-22-94$ & $<1$ & $<10$ & -- & .30 & -- & $<1$ & -- & 1 & -- & $<1$ & -- & $<1$ \\
\hline & $08-22-95$ & $<1$ & -- & $<0.1$ & -- & $<1$ & -- & $<1$ & -- & $<1$ & -- & $<1.0$ & -- \\
\hline 2 & $08-16-93$ & $<1$ & $<10$ & $<.1$ & $<.10$ & $<10$ & $<1$ & $<10$ & $<1$ & $<1$ & $<1$ & $<1.0$ & $<1$ \\
\hline \multirow[t]{2}{*}{3} & $08-16-93$ & $<1$ & $<10$ & -- & $<.10$ & $<10$ & $<1$ & $<10$ & $<1$ & $<1$ & $<1$ & $<1.0$ & $<1$ \\
\hline & $09-22-94$ & $<1$ & $<10$ & -- & .30 & -- & $<1$ & -- & $<1$ & -- & $<1$ & -- & $<1$ \\
\hline
\end{tabular}

\begin{tabular}{cccccc}
\hline $\begin{array}{c}\text { Site } \\
\text { identifier } \\
\text { shown on } \\
\text { figure 1 } \\
\text { inset }\end{array}$ & Date & $\begin{array}{c}\text { Strontium, } \\
\text { dissolved }\end{array}$ & $\begin{array}{c}\text { Vanadium, } \\
\text { dissolved }\end{array}$ & $\begin{array}{c}\text { Zinc, } \\
\text { dissolved }\end{array}$ & $\begin{array}{c}\text { Zinc, } \\
\text { total } \\
\text { recover- } \\
\text { able }\end{array}$ \\
\hline 1 & $09-22-94$ & -- & -- & -- & 20 \\
& $09-22-94$ & -- & -- & -- & $<10$ \\
& $08-22-95$ & -- & -- & 5 & -- \\
2 & $08-16-93$ & 23 & $<6$ & $<3$ & $<10$ \\
3 & $08-16-93$ & 23 & $<6$ & 17 & 10 \\
& $09-22-94$ & -- & -- & -- & $<10$ \\
\hline
\end{tabular}



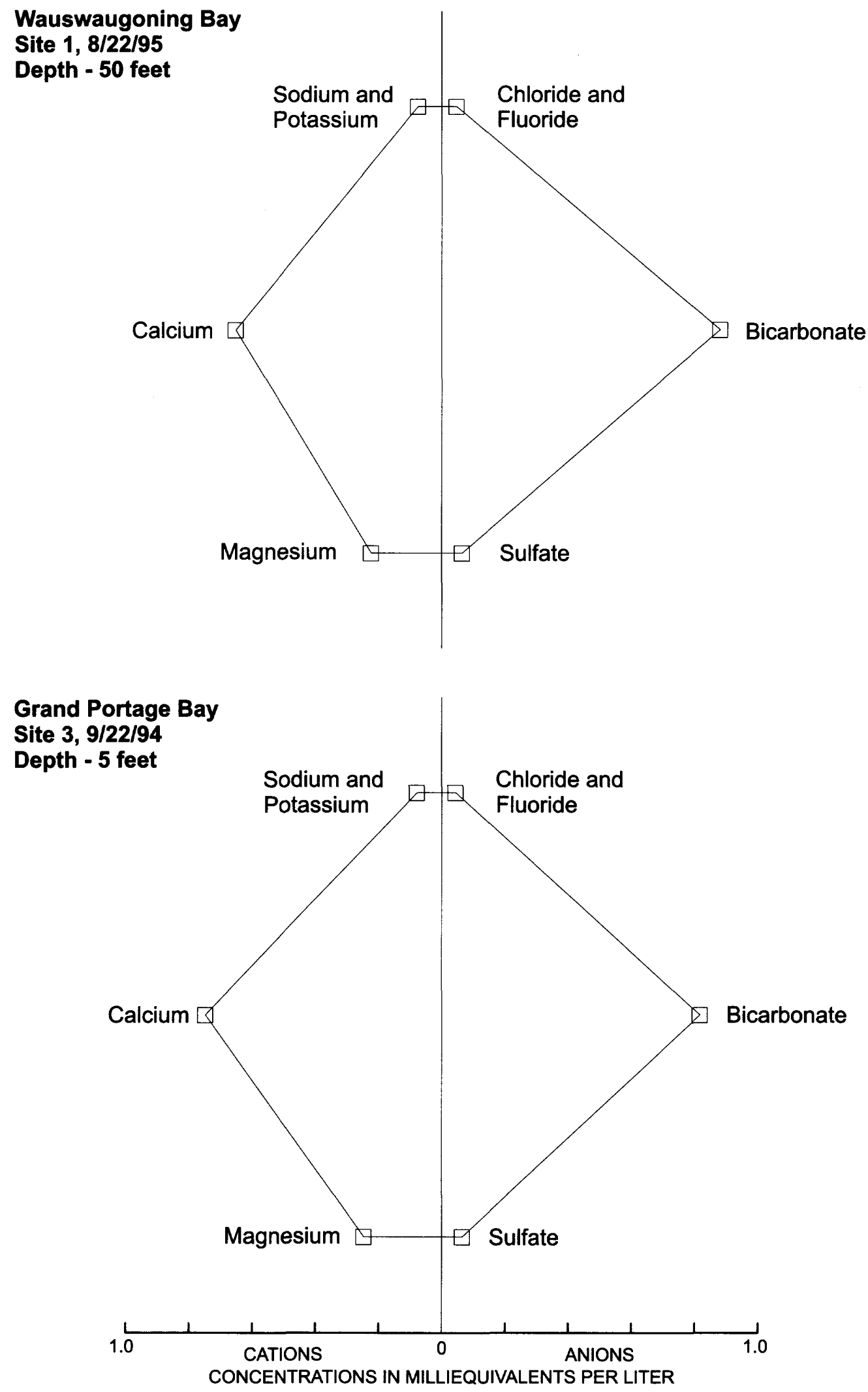

Figure 3. Water-quality diagrams of ionic composition for water from Grand Portage and Wauswaugoning Bays, Lake Superior, Grand Portage Indian Reservation, northeastern Minnesota, 1994-95 (sites shown on figure 1). 
Table 4. - Pesticide, phenol, and asbestos concentrations in water samples from

Wauswaugoning Bay, Lake Superior, Grand Portage Indian Reservation, northeastern Minnesota, 1995.

[concentrations are micrograms per liter except asbestos; <, less than; E, estimated]

\begin{tabular}{|c|c|c|c|c|c|c|c|c|c|c|}
\hline $\begin{array}{c}\text { Site } \\
\text { identifier } \\
\text { for site } \\
\text { shown on } \\
\text { figure } 1 \\
\text { inset }\end{array}$ & Date & $\begin{array}{l}\text { Depth at } \\
\text { sample } \\
\text { location, } \\
\text { total (feet) }\end{array}$ & $\begin{array}{c}\text { Sampling } \\
\text { depth } \\
\text { (feet) }\end{array}$ & $\begin{array}{l}\text { Deethyl- } \\
\text { atrazine }{ }^{1} \text {, } \\
\text { dissolved }\end{array}$ & $\begin{array}{c}\text { Cyanazine }{ }^{1}, \\
\text { dissolved }\end{array}$ & $\begin{array}{c}\text { Metolachlor' } \\
\text { dissolved }\end{array}$ & $\begin{array}{l}\text { Atrazine }^{1} \text {, } \\
\text { dissolved }\end{array}$ & $\begin{array}{l}\text { DCPA }^{2}, \\
\text { dissolved }\end{array}$ & $\begin{array}{c}\text { Phenols, } \\
\text { total }\end{array}$ & $\begin{array}{c}\text { Asbestos, } \\
\text { (million } \\
\text { structures } \\
\text { per liter) }\end{array}$ \\
\hline \multirow[t]{2}{*}{1} & $08-22-95$ & 106 & 1.0 & E0.003 & $<0.005$ & $<0.002$ & 0.005 & E0.000 & - & $<0.05$ \\
\hline & $08-22-95$ & 106 & 50.0 & E.003 & E.004 & E.002 & .006 & E.000 & $<1$ & $<.05$ \\
\hline
\end{tabular}

1 Triazine herbicide

${ }^{2}$ Chlorobenzoic acid herbicide

Pesticides (analytical reporting limit in $\mu \mathrm{g} / \mathrm{L}$ in parentheses) not detected were: propchlor (0.007); butylate (0.002); simazine (0.005); prometon (0.018); fonofos (0.003); alpha-BHC (0.002); p,p', DDE (0.006); chlorpyrifos (0.004); lindane (0.004); dieldrin (0.001); malathion (0.005); parathion (0.004); diazinon (0.002); alachlor 0.002); acetochlor (0.002); metribuzin (0.004); 2,6-diethylaniline (0.003); trifluralin (0.002); ethalfluralin (0.004); phorate $(0.002)$; terbacil $(0.007)$; linuron (0.002); methylparathion (0.006); EPTC (0.002); pebulate (0.004); tebuthiuron (0.010); molinate (0.004); ethoprop ( 0.003$)$; benfluralin ( 0.002$)$; carbofuran (0.003); terbufos (0.013); pronamide (0.003); disulfoton (0.017); triallate (0.001); propanil (0.004); carbaryl $(0.003)$; thiobencarb $(0.002)$; pendimethalin $(0.004)$; napropamide (0.003); propargite (0.013); methylazinphos (0.001); and permethrin (0.005). 
Table 5. - Trace-metal concentrations in suspended- and bottom-sediment samples from Grand Portage Bay, Grand Portage Indian Reservation, Northeastern Minnesota, 1993.

$[--$, no data; concentrations are in $\mu \mathrm{g} / \mathrm{g}$; all suspended-sediment concentrations are total;

all bottom-sediment concentrations are total recoverable except arsenic and selenium, which are total.]

\begin{tabular}{|c|c|c|c|c|c|c|c|c|}
\hline $\begin{array}{c}\text { Site } \\
\text { Identifier } \\
\text { for sites } \\
\text { shown on } \\
\text { figure } 1 \\
\text { inset }\end{array}$ & Date & Antimony & & Arsenic & Aluminum & Barium & Beryllium & Cadmium \\
\hline $3\left({ }^{1} S\right)$ & $08-16-93$ & 4.6 & & 8.1 & 4,000 & -- & -- & 4.5 \\
\hline $4\left({ }^{2} \mathrm{~B}\right)$ & $08-16-93$ & -- & & 6 & 8,600 & 20 & $<1$ & $<1$ \\
\hline $5(\mathrm{~B})$ & $08-16-93$ & -- & & 5 & 7,500 & 20 & $<1$ & $<1$ \\
\hline $6(B)$ & $08-16-93$ & -- & & 5 & 8,700 & 30 & $<1$ & $<1$ \\
\hline $7(\mathrm{~B})$ & $08-16-93$ & -- & & 3 & 6,300 & 20 & $<1$ & $<1$ \\
\hline $\begin{array}{c}\text { Site } \\
\text { Identifier fo } \\
\text { sites shown } \\
\text { on figure } 1 \\
\text { inset }\end{array}$ & Chromium & & Iron & & Lead & Manganese & Mercury & Nickel \\
\hline $3\left({ }^{1} S\right)$ & 475 & & 6,000 & & 315 & 285 & 0.55 & 135 \\
\hline $4\left({ }^{2} \mathrm{~B}\right)$ & 20 & & -- & & $<10$ & -- & $<.01$ & 10 \\
\hline $5(\mathrm{~B})$ & 10 & & -- & & $<10$ & -- & $<.01$ & 10 \\
\hline $6(\mathrm{~B})$ & 20 & & -- & & $<10$ & -- & $<.01$ & 20 \\
\hline $7(\mathrm{~B})$ & 10 & & -- & & $<10$ & -- & $<.01$ & 10 \\
\hline
\end{tabular}

\begin{tabular}{ccccc}
\hline $\begin{array}{c}\text { Site } \\
\text { Identifier for } \\
\text { sites shown } \\
\text { on figure } 1 \\
\text { inset }\end{array}$ & Selenium & Silver & Titanium & Zinc \\
\hline $2(\mathrm{~S})$ & 1.1 & $<2.5$ & 0.1 & 365 \\
$4(\mathrm{~B})$ & $<1$ & -- & -- & 50 \\
$5(\mathrm{~B})$ & $<1$ & -- & -- & 40 \\
$6(\mathrm{~B})$ & $<1$ & -- & -- & 50 \\
$7(\mathrm{~B})$ & $<1$ & -- & -- & 30 \\
\hline
\end{tabular}

${ }^{1}$ Suspended-sediment concentration.

${ }^{2}$ Bottom-sediment concentration. 